\section{REFERENCES}

Antoniou AC, Pharoah PP, Smith P, Easton DF (2004) The BOADICEA model of genetic susceptibility to breast and ovarian cancer. $\mathrm{Br}$ J Cancer 91: $1580-1590$

Claus EB, Risch N, Thompson WD (1991) Genetic analysis of breast cancer in the cancer and steroid hormone study. Am J Hum Genet 48: $232-242$

Claus EB, Risch N, Thompson WD (1994) Autosomal dominant inheritance of early onset breast cancer. Cancer 73: 643-651

Jonker MA, Jacobi CE, Hoogendoorn WE, Nagelkerke NJ, de Bock GH, van Houwelingen JC (2003) Modeling familial clustered breast cancer using published data. Cancer Epidemiol Biomarkers Prev 12: $1479-1485$

Parmigiani G, Berry D, Aguilar O (1998) Determining carrier probabilities for breast cancer-susceptibility genes BRCA1 and BRCA2. Am J Hum Genet 62: $145-158$

Van Asperen CJ, Jonker MA, Jacobi CE, van Diemen-Homan JE, Bakker E, Breuning MH, van Houwelingen JC, de Bock GH (2004) Risk estimation for healthy women from breast cancer families: new insights and new strategies. Cancer Epidemiol Biomarkers Prev 13: 87-93

\title{
Reply: Remarks on the BOADICEA model of genetic susceptibility to breast and ovarian Cancer Research UK
}

\author{
AC Antoniou', PDP Pharoah ${ }^{2}$, AP Cunningham' and DF Easton ${ }^{*, 1}$ \\ 'Cancer Research UK, Genetic Epidemiology Unit, Strangeways Research Laboratory, Department of Public Health and Primary Care, University of \\ Cambridge CBI 4RN, UK; ${ }^{2}$ Cancer Research UK, Human Cancer Genetics Group, Department of Oncology, University of Cambridge, CBI 4RN, UK
}

British Journal of Cancer (2005) 92, I337- 1338. doi:I0.1038/sj.bjc.6602488 www.bjcancer.com

Published online 22 March 2005

(c) 2005 Cancer Research UK

Sir,

The BOADICEA model of genetic susceptibility to breast and ovarian cancer was developed using complex segregation analysis of breast and ovarian cancer (Antoniou et al, 2002, 2004). We agree with van Asperen et al that as it stands, the model is not easy to use in clinical practice. However, the model is currently being implemented in web-based software that will provide a userfriendly tool for clinical geneticists and oncologists. We disagree however with the premise that the model is particularly hard to understand. The BOADICEA model incorporates the effects of BRCA1, BRCA2 and other genes. Although it has more risk parameters than some other models, it is conceptually quite similar to the Claus et al (1991) or BRCAPRO models (Parmigiani et al, 1998), or the model proposed by Jonker et al (2003). The major difference is the incorporation of a polygenic component to explain familial aggregation of breast cancer not attributable to BRCA1 and BRCA2.

van Asperen et al question the low breast cancer risk (13\% by age 70) estimated for the index woman in Figure 3 of our paper. We agree that this estimate is probably anomalously low, due to imprecision in the BRCA1 and BRCA2 penetrance estimates we used. The average risk of breast cancer in BRCA1 mutation carriers in the first version of the BOADICEA model was estimated to be $35 \%$ by age 70 (Antoniou et al, 2002), which is much lower than the estimates used in the Jonker et al (2003). However, the BRCA1 and BRCA2 incidence rates used in the first version of BOADICEA were

*Correspondence: Professor DF Easton:

E-mail: doug.easton@srl.cam.ac.uk

Published online 22 March 2005 based on relatively small numbers of BRCA1 and BRCA2 mutation positive families (62 in total) and may therefore be imprecise.

To improve the risk prediction, we have recently refitted the BOADICEA model using additional data from two UK populationbased studies of breast cancer (Peto et al, 1999; Lalloo et al, 2003) and data from the meta-analysis of the families of BRCA1/2 carriers identified through population-based studies of breast and ovarian cancer (Antoniou et al, 2003). The updated data set includes more than 500 BRCA1 and BRCA2 mutation positive families, and therefore the incidence rates are estimated more reliably (manuscript in preparation). In the updated version, the average risk of breast cancer in BRCA1 mutation carriers by age 70 varies between 50 and $59 \%$ depending on the year of birth. Applying the latest version of the model to the family in Figure 2 of Antoniou et al (2004), the 40-year-old woman is predicted to carry a BRCA1 mutation with probability $41 \%$ and a BRCA2 mutation with a probability $1 \%$ (very similar to the previous estimates). However, her predicted risk of developing breast cancer by age 70 is now higher, $28 \%$, perhaps closer to the expectations of van Asperen and co-workers.

van Asperen et al question the fact that the presence of ovarian cancer in the family does not affect the breast risk. It is a feature common to BOADICEA and all the other risk prediction models, however, that the risks of breast and ovarian cancer in a family are assumed to be independent given the BRCA1 and BRCA2 genotypes. Thus, the presence of ovarian cancer in the family only affects the breast cancer risk in so far as it affects the BRCA1 and BRCA2 carrier probabilities.

We agree that the regression model of van Asperen et al (2004) can be more easily used in clinical practice. However, this model cannot deal with the complex family histories seen in genetic 
clinics. Moreover, the model was derived by linear regression of the independent variables on the predictions given the Jonker et al (2003) model. Therefore, the validity of the regression formula critically depends on an as yet (to our knowledge) unvalidated

\section{REFERENCES}

Antoniou AC, Pharoah PD, McMullan G, Day NE, Stratton MR, Peto J, Ponder BJ, Easton DF (2002) A comprehensive model for familial breast cancer incorporating BRCA1, BRCA2 and other genes. Br J Cancer 86: $76-83$

Antoniou A, Pharoah PD, Narod S, Risch HA, Eyfjord JE, Hopper JL, Loman N, Olsson H, Johannsson O, Borg A, Pasini B, Radice P, Manoukian S, Eccles DM, Tang N, Olah E, Anton-Culver H, Warner E, Lubinski J, Gronwald J, Gorski B, Tulinius H, Thorlacius S, Eerola H, Nevanlinna H, Syrjakoski K, Kallioniemi OP, Thompson D, Evans C, Peto J, Lalloo F, Evans DG, Easton DF (2003) Average risks of breast and ovarian cancer associated with BRCA1 or BRCA2 mutations detected in case series unselected for family history: a combined analysis of 22 studies. Am J Hum Genet 72: 1117-1130

Antoniou AC, Pharoah PP, Smith P, Easton DF (2004) The BOADICEA model of genetic susceptibility to breast and ovarian cancer. Br J Cancer 91: $1580-1590$

Claus EB, Risch N, Thompson WD (1991) Genetic analysis of breast cancer in the cancer and steroid hormone study. Am J Hum Genet 48: $232-242$ model. In any event, evaluation of the accuracy of any model in predicting the correct carrier and cancer risks should be based on validation studies in independent series and not on the basis of individual families.
Jonker MA, Jacobi CE, Hoogendoorn WE, Nagelkerke NJ, de Bock GH, van Houwelingen JC (2003) Modeling familial clustered breast cancer using published data. Cancer Epidemiol Biomarkers Prev 12: $1479-1485$

Lalloo F, Varley J, Ellis D, Moran A, O’Dair L, Pharoah P, Evans DG (2003) Prediction of pathogenic mutations in patients with early-onset breast cancer by family history. Lancet 361: 1101-1102

Parmigiani G, Berry D, Aguilar O (1998) Determining carrier probabilities for breast cancer-susceptibility genes BRCA1 and BRCA2. Am J Hum Genet 62: $145-158$

Peto J, Collins N, Barfoot R, Seal S, Warren W, Rahman N, Easton DF, Evans C, Deacon J, Stratton MR (1999) Prevalence of BRCA1 and BRCA2 gene mutations in patients with early-onset breast cancer. $J$ Natl Cancer Inst 91: $943-949$

van Asperen CJ, Jonker MA, Jacobi CE, Diemen-Homan JE, Bakker E, Breuning MH, van Houwelingen JC, de Bock GH (2004) Risk estimation for healthy women from breast cancer families: new insights and new strategies. Cancer Epidemiol Biomarkers Prev 13: $87-93$ 